\title{
Water Bodies an Urban Microclimate: A Review
}

\author{
Golnoosh Manteghi ${ }^{1}$, Hasanuddin bin limit ${ }^{1} \&$ Dilshan Remaz ${ }^{1}$ \\ ${ }^{1}$ Centre for Study of Built Environment in the Malay World (KALAM), Faculty Built Environment, University \\ Technology Malaysia, UTM Skudai, Johor, Malaysia \\ Correspondence: Golnoosh Manteghi, Centre for Study of Built Environment in the Malay World (KALAM), \\ Faculty Built Environment, University Technology Malaysia, UTM Skudai, 81310, Johor, Malaysia. Tel: \\ 60-111-069-2007. E-mail: mgolnoosh2@live.utm.my
}

\author{
Received: November 19, 2014 Accepted: December 13, 2014 Online Published: February 2, 2015 \\ doi:10.5539/mas.v9n6p1 \\ URL: http://dx.doi.org/10.5539/mas.v9n6p1
}

The research is financed by centre for Study of Built Environment in the Malay World (KALAM)

\begin{abstract}
In urban areas, water bodies have a positive effect upon microclimate of the surroundings with the relative cooling impact it has on evaporative procedure. Hence, evaporative cooling might be one of the pretty efficient methods of passive cooling for urban spaces and buildings. Differences in temperature between the urban space and the non-urban space which surrounds, is dubbed UHI (Urban Heat Island) effect. Water bodies have also been proven to be influential methods of decreasing urban temperatures. A water body temperature is capable of being lower than the surrounding urban environment around $2-6^{\circ} \mathrm{C}$. According to these findings; one may conclude that the rise of evapotranspiration in cities, that has roots in vegetation and water body, can efficiently mitigate the influence of the urban heat island. Unfortunately, the effect that water bodies can have upon urban temperatures has not been thoroughly assessed in previous studies, specifically the difference between the daytime and night time influences of water bodies, and the matter the how urban design may be in influential in moving the cooling influence from the water bodies toward the city. This paper provides a theoretical background for the problem and reviews the related literature.
\end{abstract}

Keywords: urban heat islands, water bodies, temperature, heat mitigation

\section{Introduction}

Urbanization and transformation of the earth surface to urban application illustrate huge changes in global usage of the land and provide considerable influence on the environment (Weng and Yang, 2004). The population in global urban areas has risen quickly from $13 \%$ in 1900 up to $46 \%$ in 2000 , and it is believed that it can go up to $69 \%$ by 2050 .

Based on the Intergovernmental Panel on Climate Change (IPCC), the average global temperature is believed to rise by around 1.8 to 4.0 by the 21 st century end. The influence of climate change is foreseeable in the shape of altering weather patterns and extreme weather events, like heavy rainfall, flood, windstorm, heat waves and windstorms (IPCC, 2007).

Extreme hot weather events and heat waves regard to a rising public health challenge in due to the higher heat-related deaths, something that adds to the global issue of disease (EEA, 2012; Kovatis and Hajat, 2008; Comrie, 2007, D'Ippppoliti et al, 2010).

The human organism continuously makes a balance between individual energy losses of heat and maintains the body core temperature in the range of $36.1-37.8^{\circ} \mathrm{C}$. Thermal budget can be strongly influenced by electromagnetic waves that are coming from the sun, evaporation of sweat and convection in the surrounding air. Even rise of a temperature for just around $1{ }^{\circ} \mathrm{C}$ can trigger a powerful regulation mechanism by increasing skin perfusion and sweating. Although, this group of thermal regulation mechanisms can be stressful to organisms, specifically for cardiac system. Therefore, high levels of heat exposure may result in big health problems ranging from normal heat rashes, heat cramps and heat exhaustion to lethal heart strokes (Kjellstrom et al, 2012; WHO, 2008). A number of factors in specific are particularly associated with overall mortality and morbidity during the heat waves, involving gender, age, socio-economic status, premorbidity and interdependencies with path 
physical and clinical factors (EEA, 2012; Pauli and Hornberg, 2010; Kovatas and Hajat, 2008; WHO, 2008). Older people health is more impaired by the matter of co-morbidity, cognitive and physical impairment and also multiple medications (D'Ippppoliti et al, 2010; Hajat et al. 2010). Children and infant, since their metabolism is not as effective as the one from adults, people who suffer from chronic diseases, people who are using medications, which affect the body mechanism of thermoregulation, people who are socio economically deprived, and people in situations that include large levels of outdoor activity are also under threat from high temperatures (WHO, 2012).

Because the great thermal mass is made from asphalt, the dark covers of streets and roofs, bricks and concrete, heat output by industry, low evapotranspiration, motor vehicles and households, in addition to the low ventilation capacity of regions that have buildings, temperatures of an ambient air inside urban areas can be around $10 \mathrm{C}$ higher than similar rural areas, that forms an "Urban Heat Island" (UHI) under the specific conditions (Oke, 1992; Arnfield, 2003; Santamouris et.al, 2001).

Higher temperatures for urban areas may increase the usage of energy, due to a larger need for air conditioning, and since power plants consume more fossil fuels, they overdrive both energy costs and pollution levels (Weng and Yang, 2004). Hence, there is a big urgency to assess strategies, which can mitigate further rises in urban temperatures (Bowler et al, 2010).

It is quite important for health professional and city planners to evaluate and develop strategies for mitigate and transformation of climate change, specifically in urban areas (Rydin et al. 2012; Smith and Levermore, 2008). Therefore, the distribution for the effect of UHI is then positively correlated with the density, dimensions and city designs (Arnfield, 2003; Oke, 1992). An adaptation strategy in order to cool down towns and cities are belied to lead in the direction of "greening" the urban regions (Bowler et. al, 2010a). Urban green has a large potential to ameliorate the climate of urban areas by the procedures of evapotranspiration of leaves, shading and offering surfaces and areas for water evaporation (Givoni, 1991; Taha et al, 1988). Evidence on the cooling capability of urban green being enough powerful to cool down the environment on the local scale is explained in brief in the literature review done by Bowler et al (2010b). The meta analysis done in that study proposed that a cooling impact of the vegetation inside urban parks by the rate of $1 \mathrm{C}$ on average in comparison to non-green regions and reflects the results of the current studies (Coutts et al, 2012; Li et al, 2011; Peng et al, 2012).

Water bodies are also particularly supposed to assist in cooling down the air around them via evaporation (Oke, 1992) and convection (Spronken-Smith et al, 2000). And this matter has provided the core question for the current study: what is the cooling role of water bodies in the microclimates around them?

Hence a review study was done on the empirical evidence on the capacity of temperature mitigating of the water bodies. Furthermore, there was some research on the roles of evapotranspiration of the body water in alleviating the UHI effect, which is based on the results of the mentioned investigation and also from the previous published works. These kinds of results can offer helpful information for urban planning and design. Figure 1

\section{Overview of Studies}

Similar to the cooling impacts of parks (Upmanis et al, 1998; Coutts et al, 2012), water bodies are likely to offer downwind cooling effect. Open water bodies offer a source for moisture in an order to back up the oasis effect over day duration, specifically when the region is invaded by drier, larger-scale warmer surroundings (Spoken-Smith et al., 2000; Oke, 1992; Coutts et al, 2012) of urban environment.

On the other hand, a number of studies which report the water effectiveness in urban mitigation are pretty rare. Only a small number of studies hypothesize water bodies in shape of the strongest cooling element in a city over the hot days of summer (Theeuwas et al, 2013; Rinner et al, 2011; Olah, 2012).

\subsection{Cooling Effects of Evaporation from Water Bodies}

Within an urban region water features can have positive influence on the microclimate of the surrounding regions when the natural cooling coming from the evaporation will be required in the hot sunny days. The more chances of water availability generally improve evaporation, and the related lift of latent heat offers and extra daytime cooling influence. Water bodies work as the cooling source of the microclimate of surrounding region. The temperature of the air above and near water body is different from the temperature over the land because the water has a different system of cooling and heating. Water bodies are believed to be the best radiation absorbers, but on the other hand, they provide a very small thermal response (Wong et al, 2012; Oke, 1992).

Unlimited availability of waters assists to an effective latent heat sink, and evaporative cooling tends toward destabilizing the layer of surface and further improves mixing. These characteristics result in the surface temperature of the water bodies to be cooler than the same on land. A cooler surface leads to a cooler air 
temperature on their above (Wong et al, 2012).

Table 1. Summary of studies related to cooling effects of water bodies

\begin{tabular}{|c|c|c|c|c|c|c|c|c|c|}
\hline No. & Author & Publication & Study location & Region & Feature of water body & Method & Study & Scale & \\
\hline 1 & Chen et al. & 2006 & China & $\begin{array}{l}\text { Tropical warm } \\
\text { semi-humid }\end{array}$ & River area and fish ponds compare to built up area & Remote Sensing & - & $\begin{array}{l}\text { Macro } \\
\text { Scale }\end{array}$ & - \\
\hline 2 & Peng $\mathrm{H}$ et al. & 2009 & Beijing, China & $\begin{array}{l}\text { Subtropical } \\
\text { continental } \\
\text { semi-humid }\end{array}$ & Urban wetlands compared to urban region & Remote Sensing & Day & $\begin{array}{l}\text { Macro } \\
\text { Scale }\end{array}$ & - \\
\hline 3 & Peng $\mathrm{H}$ et al. & 2013 & Beijing, China & $\begin{array}{l}\text { Subtropical } \\
\text { continental } \\
\text { semi-humid }\end{array}$ & Urban wetlands compared to residential area & Remote Sensing & Day & $\begin{array}{l}\text { Macro } \\
\text { Scale }\end{array}$ & - \\
\hline 4 & Li et al. & 2011 & Shanghai, China & $\begin{array}{l}\text { Subtropical } \\
\text { continental humid }\end{array}$ & Water areas compared to urban areas & Remote Sensing & - & $\begin{array}{l}\text { Macro } \\
\text { Scale }\end{array}$ & - \\
\hline 5 & Shudo et al. & 1997 & $\begin{array}{l}\text { Western Hokkaido } \\
\text { Island, Japan }\end{array}$ & $\begin{array}{l}\text { Maritime warm } \\
\text { moderate humid }\end{array}$ & $\begin{array}{l}\text { Water (inland waters, seashore, seas) compared to all other } \\
\text { land uses (man-made, agricultural, woods and forests) }\end{array}$ & $\begin{array}{l}\text { Remote Sensing and } \\
\text { On-site Measurement }\end{array}$ & - & $\begin{array}{l}\text { Macro } \\
\text { Scale }\end{array}$ & - \\
\hline 6 & $\begin{array}{l}\text { Sun and } \\
\text { Chen }\end{array}$ & 2012 & Beijing, China & $\begin{array}{l}\text { Subtropical } \\
\text { continental } \\
\text { semi-humid }\end{array}$ & $\begin{array}{l}\text { Water bodies (excluding rivers and canals) compared to } \\
\text { built-up land }\end{array}$ & Remote Sensing & Day & $\begin{array}{l}\text { Macro } \\
\text { Scale }\end{array}$ & - \\
\hline 7 & Sun et al. & 2012 & Beijing, China & $\begin{array}{l}\text { Subtropical } \\
\text { continental } \\
\text { semi-humid }\end{array}$ & Lakes, river, reservoirs compared to built-up area & Remote Sensing & Day & $\begin{array}{l}\text { Macro } \\
\text { Scale }\end{array}$ & - \\
\hline 9 & Han et al. & 2011 & Wuhan, China & $\begin{array}{l}\text { Subtropical } \\
\text { continental humid }\end{array}$ & Urban river compared to urban block & On-site Measurement & Day & $\begin{array}{l}\text { Meso } \\
\text { Scale }\end{array}$ & - \\
\hline 10 & Huang et.al & 2008 a & Nanjing, China & $\begin{array}{l}\text { Subtropical } \\
\text { continental humid }\end{array}$ & Urban lake compared to city centre & On-site Measurement & $\begin{array}{l}\text { Day and } \\
\text { Night }\end{array}$ & $\begin{array}{l}\text { Meso } \\
\text { Scale }\end{array}$ & - \\
\hline 11 & Huang et al. & $2008 \mathrm{~b}$ & Nanjing, China & $\begin{array}{l}\text { Subtropical } \\
\text { continental humid }\end{array}$ & Urban lake compared to city centre & On-site Measurement & $\begin{array}{l}\text { Day and } \\
\text { Night }\end{array}$ & $\begin{array}{l}\text { Meso } \\
\text { Scale }\end{array}$ & - \\
\hline 12 & ISHII et al. & 1991 & Fukuoka, Japan & $\begin{array}{l}\text { Subtropical } \\
\text { continental humid }\end{array}$ & $\begin{array}{l}\text { 1) Park with pond, 2) park without pond compared to } \\
\text { built-up residential area }\end{array}$ & On-site Measurement & Day & $\begin{array}{l}\text { Meso } \\
\text { Scale }\end{array}$ & - \\
\hline 13 & Kim et al. & 2008 & Seoul, South Korea & $\begin{array}{l}\text { Subtropical } \\
\text { continental humid }\end{array}$ & $\begin{array}{l}\text { Restored downtown stream on surface compared to } \\
\text { downtown area with stream in canal }\end{array}$ & On-site Measurement & Day & $\begin{array}{l}\text { Meso } \\
\text { Scale }\end{array}$ & - \\
\hline 14 & Kim et al. & 2008 & Seoul, South Korea & $\begin{array}{l}\text { Subtropical } \\
\text { continental humid }\end{array}$ & $\begin{array}{l}\text { Restored downtown stream on surface compared to } \\
\text { downtown area in } 200 \mathrm{~m} \text { distance }\end{array}$ & On-site Measurement & Day & $\begin{array}{l}\text { Meso } \\
\text { Scale }\end{array}$ & - \\
\hline 15 & Lopes et al. & 2011 & Funchal, Portugal & $\begin{array}{l}\text { Subtropical maritime } \\
\text { semi-humid }\end{array}$ & $\begin{array}{l}\text { Shore line compared to urban valley bottom in } 780 \mathrm{~m} \\
\text { distance }\end{array}$ & On-site Measurement & Day & $\begin{array}{l}\text { Meso } \\
\text { Scale }\end{array}$ & - \\
\hline 16 & Lopes et al. & 2011 & Funchal, Portugal & $\begin{array}{l}\text { Subtropical maritime } \\
\text { semi-humid }\end{array}$ & $\begin{array}{l}\text { Shore line compared to urban area near shoreline in } 75 \mathrm{~m} \\
\text { distance }\end{array}$ & On-site Measurement & Day & $\begin{array}{l}\text { Meso } \\
\text { Scale }\end{array}$ & \\
\hline 17 & $\begin{array}{l}\text { Murakawa et } \\
\text { al. }\end{array}$ & 1991 & Hiroshima, Japan & $\begin{array}{l}\text { Subtropical } \\
\text { continental humid }\end{array}$ & Urban channel compared to urban quarter in $400 \mathrm{~m}$ distance & On-site Measurement & $\begin{array}{l}\text { Day } \\
\text { and Night }\end{array}$ & $\begin{array}{l}\text { Meso } \\
\text { Scale }\end{array}$ & - \\
\hline 19 & $\begin{array}{l}\text { Murakawa et } \\
\text { al. }\end{array}$ & 1991 & Hiroshima, Japan & $\begin{array}{l}\text { Subtropical } \\
\text { continental humid }\end{array}$ & Urban river compared to urban quarter & On-site Measurement & Day & $\begin{array}{l}\text { Meso } \\
\text { Scale }\end{array}$ & - \\
\hline 20 & $\begin{array}{l}\text { Schwarz et } \\
\text { al. }\end{array}$ & 2012 & Leipzig, Germany & $\begin{array}{l}\text { Maritime warm } \\
\text { moderate humid }\end{array}$ & Water compared to urban area & Remote Sensing & Day & $\begin{array}{l}\text { Meso } \\
\text { Scale }\end{array}$ & - \\
\hline 21 & Tuller & 1995 & Victoria, Canada & $\begin{array}{l}\text { Maritime warm } \\
\text { moderate humid }\end{array}$ & Urban waterfront compared to varying urban inland sites & On-site Measurement & Day & $\begin{array}{l}\text { Meso } \\
\text { Scale }\end{array}$ & - \\
\hline 22 & $\begin{array}{l}\text { Nishimura et } \\
\text { al. }\end{array}$ & 1998 & Osaka, Japan & $\begin{array}{l}\text { Subtropical } \\
\text { continental humid }\end{array}$ & Water pond without fountain compared to park & On-site Measurement & $\begin{array}{l}\text { Day } \\
\text { and Night }\end{array}$ & $\begin{array}{l}\text { Micro } \\
\text { Scale }\end{array}$ & - \\
\hline
\end{tabular}




\begin{tabular}{|c|c|c|c|c|c|c|c|c|}
\hline 23 & $\begin{array}{l}\text { Nishimura et } \\
\text { al }\end{array}$ & 1998 & Osaka, Japan & $\begin{array}{l}\text { Subtropical } \\
\text { continental humid }\end{array}$ & Water pond with fountain compared to park & On-site Measurement & $\begin{array}{l}\text { Day } \\
\text { and Night }\end{array}$ & $\begin{array}{l}\text { Micro } \\
\text { Scale }\end{array}$ \\
\hline 24 & Saarom et al. & 2000 & $\begin{array}{l}\text { Tel-Aviv, } \\
\text { Israel }\end{array}$ & meditation & Seashore compare to city canter and rural area & On-site Measurement & Day & $\begin{array}{l}\text { Micro } \\
\text { Scale }\end{array}$ \\
\hline 25 & Ishii et al. & 1991 & Fukuoka, Japan & $\begin{array}{l}\text { Subtropical } \\
\text { continental humid }\end{array}$ & Pond in park compared to the same park whit out pond & On-site Measurement & Day & $\begin{array}{l}\text { Micro } \\
\text { Scale }\end{array}$ \\
\hline 26 & Chen et al. & 2009 & Guangzhou, China & $\begin{array}{l}\text { Tropical warm, semi } \\
\text { humid }\end{array}$ & Pond compared to Built-up area & On-site Measurement & Day & $\begin{array}{l}\text { Micro } \\
\text { Scale }\end{array}$ \\
\hline
\end{tabular}

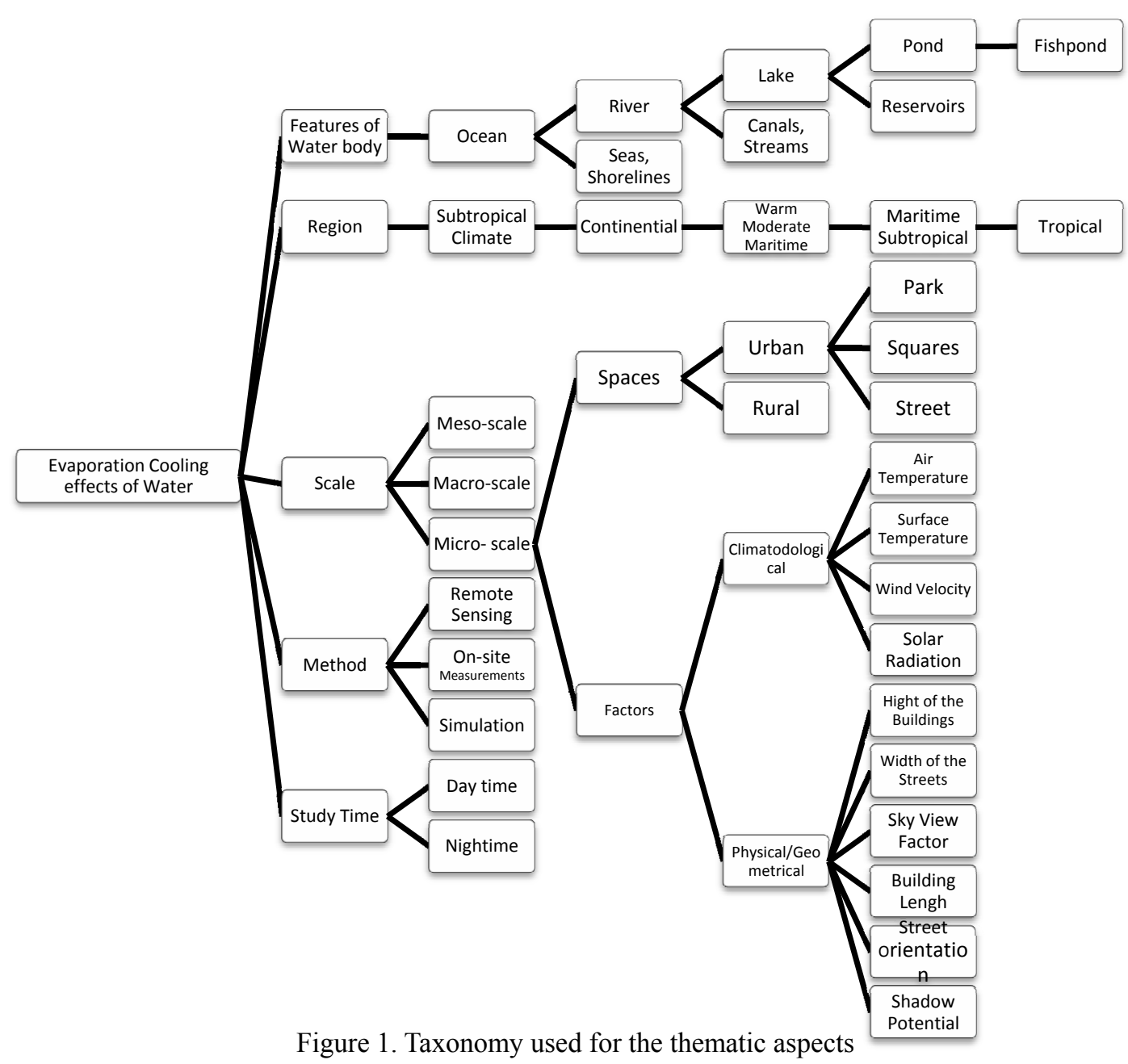

A lot of researchers proposed that evaporative cooling from water features or water bodies is still one of the most effective methods of passive cooling in urban spaces and buildings (Wong et al, 2012; Kruger and Pearlmuuter, 2008).

Enriched evaporation is capable of lowering the air temperature and hence mitigates the process of UHI and arises the inhabitants' thermal comfort. Arisen evaporation may be reached via increasing the vegetation or the surface water`s amount.

A large number of studies have analysed the influences of the open water bodies (whether they treat ponds, wet lands, water features or rivers) on the urban regions climate (amongst other $\mathrm{Xu}$ et al, 2010; and Sun and Chen, 2012).

Usually, studies declare that temperatures closed to and downwind from water bodies are getting reduced about 1-2 $\mathrm{C}$ in comparison to surrounding areas, with the highest amount of temperature reduction observed through 
the day (Coutts et al, 2012; Chen et al, 2009; Saaroni and Ziv, 2003 Nishimura et al, 1998). Chen et al. (2009) dedicated this reduction of temperature to evaporation from the water body, as Saaroni and Ziv (2003) showed the cooling pond effect (1.6 C at mid-day) over the warmest part of a day, have decreased sensible heat flux, since the surface of the lake was somehow cooler than the grass cover of the surrounding park, and the daytime cooling influences were clearly obvious under both sultry and hot-and-dry weather conditions (Coutts et al, 2012).

In a number of cities, water is an indispensable part of daily life; like the cities next to lakes or located riverside. As an example Xu et al. 2009 applied observations to assess the effect that a water body has on thermal comfort, for all the hot days that have temperatures over $35 \mathrm{C}$. their results show that these water bodies hugely cool their littoral zones. Simultaneously, there was a modeling study carried out by Robitu et al (2006) which suggested that small ponds had some sort of cooling influence on their surroundings too. Another study concentrated on the cooling influence of water holding pavements; this study displayed a temperature decrease for several degrees (Theeuwes et al, 2013; Nakayma and Fujita, 2010).

Saaroni and Ziv (2003) study over a $100 \mathrm{~m}$ wide pond inside an urban park in Tel Aviv, Israel, also displayed higher rates of humidity and a lower amount of heat stress over the day downwind of pond. Although, in later hours of the day when the grass covers temperature lowered than the lake surface, it got cleared that evaporative cooling was the fundamental driver for temperature decrease, but this lowered humidity, and hence the raised heat stress (Coutts et al, 2012; Saaroni and Ziv, 2003). These findings propose that wetlands use for storm water treatment might also back up downwind cooling influences over the day, but potential cooling influences are depending on the condition over adjacent microclimates. Murakawa et al (1991) in Hiroshima, Japan, understood that downwind cooling influences from the Ota River are present in at least a few hundred meters. The temperature of the air around the $270 \mathrm{~m}$ wide river were about 3-5 C cooler (between 12-5 pm) than the surrounding region on fine days, and the extra local cooling from the river believed to be more widespread while building density was lower and streets were quite wider (Coutts et al, 2012; Murakawa et al, 1991).

\subsection{Effect of Thermal Capacity of Water Bodies}

In addition to the evaporation effect, water bodies have also a pretty high capacity. The thermal capacity of water is pretty large in a sense that it needs about three times more heat to raise a one-unit volume of water over the same temperature interval as the most soil (Wong et al, 2011, 2012).

In order to regulate the temperature of urban area, architects and urban planners have employed water bodies as their tools of design (Coutts et al, 2013). The idea behind employing water bodies has roots in enriched evaporation of the bodies of water during a day. Considering a non-stop net radiation, water evaporation costs energy at the value of sensible heat, which keeps the temperature of the air at a more agreeable level than not having water bodies. Sun et al, (2012) discovered a substantial decreased temperature of daytime land surface near the lalesin Beijing (China). Hatway and Sharples (2012) reported decreased air temperatures near the rivers inside UK. Furthermore, they suggested that the cooling effect was at its peak in early spring and starts to lower in June.

Eventually, the rate for the diurnal temperature of water is lower than the one from the rural area, which means the maximum temperature are getting suppressed, and nocturnal temperature drop is limited. The direct link between the air temperature and the surface translates the mentioned signal to the temperature of screen level (Heusinkveld et al, 2010; Steeneveld et al, 2014). A lot of prior studies focused on the lakes role on the urban microclimate (Givoni et al, 2003; Olah, 2012) concentrated on UHI of daytime and thermal human comfort. Although this matter covers a restricted view upon the problem, as the UHI is in its largest amount around sunset. In addition, the thermal comfort of humans at night is very important for prior sleeping (Steeneveld et al, 2014; Ihara et al, 2011), something that motivates concentrating on water bodies` role at night in urban microclimate.

All the mentioned water bodies have the ability to maintain water temperatures at a night time due to thermal inertia and high heat capacity of water. This directs the attention to the probability of treatment open water bodies and wetlands properly offering a relative warming influence at night (unless evaporative cooling is dominant) but, in comparison to urban surfaces, they might still offer a cooling impact (Coutts et al 2012).

Throughout the night, the cooling impact weakens until it vanishes (nearly around 4:00 GMT) and afterwards, the lake stops to have its cooling effect. This is normally due to the air temperature getting lower than the temperature from water. And from this time, the body of water starts to get the surroundings warmer with the highest level on intensity around 6:00 GMT (Theeuwes et al, 2013).

The water body that has a high temperature around $20 \mathrm{C}$ has a much more powerful warming effect over the 
course of the night than the cooling impact it has over the day. These results only promote the critical point which states that lakes do not only cool during the daytime, but they can also be responsible for a significant amount of warming in a city (Theeuwes et al, 2013).

These outcomes confirm the modeling outcomes by Theeuwes, Solcerove, and Steeneveld (2013), who also understood that for the warm lakes, both the wet bulb and the UHI globe temperature remain pretty high through the night. Although, the thermal sensation must be approved via interviews the urban dwellers.

\subsection{The Role of Urban Design on Water Body's Effects}

It is also quite clear that the design for the surrounding urban landscape is vital in maximizing the downwind cooling effect (Coutts et al 2012).

On the micro scale, water is considered to be pretty stable under the present weather conditions in comparison to lawn or concrete (Huang et al, 2008a) due to its larger thermal capacity (Hou et al, 2013), but other condition also do influence the efficiency of urban water. Temperature distribution is heavily related to presenting radiation condition. The cooling impact of the urban water body depends on the way radiant energy is separated into heat fluxes (Sun and Chen, 2012). By considering the rise in global solar radiation, the deviation of temperature between urban areas and water is stronger (Ishshii, 1991).

The direction and speed of wind are vital in spreading the cooling impact of urban water bodies. Wind conditions can make various patterns for temperature distribution, so can urban morphology (Kim et al, 2008). The wind is moving the above the lake to the surroundings and makes a plume of warmer or colder air downwind in city and inside rural areas. Urban streets which run downwind or a public square that is located next to a water body space acquires better thermal situations than obstructive streets (Han et al, 2011; Hathway and Sharples, 2012; Theeuwes et al, 2013).

Various wind speeds may result in various results. Another method of influencing the wind over the city is to enrich the terrain roughness, e.g., higher buildings result in higher roughness length and decrease the wind rate over the city. Hence, different urban features will have specific self-related impacts. Some of the studies did not focus on the spreading of cooling impact from water due to the surface character or wind field (Theeuwes et al, 2013).

The features of the patterns from wind flow in low levels inside urban environments are under more influence from local geometry, like trees, street geometry and the distribution of building heights, and getting less affected from the features of the upper layer flow (Ricciardelli, 2006). Ishshii et al (1991) discovered lower temperatures on present on the leewares part of a water body space. Hathway and Sharples (2012) emphasized the vitality of open spaces close to water body sites for the distribution of the temperature in comparison to obstructive or enclosed streets.

Murakawa et al (1991) suggested that the horizontal impact of the water body on the microclimate is depending on density of buildings and rivers and street's width. Due to the usually restricted amount of water bodies in city, the horizontal efficiency of cooling capacity is vital. Inside leeward direction of around 127,000 $\mathrm{m} 2$ pond located in Fukuoka, Japan Ishshii et al (1991) discovered an impact on surrounding regions around the distance of 400m. In one study which was done later, Hou et al (2013) understood that there is a $300 \mathrm{~m}$ milestone up to the amount that the wetlands can be influential. Murakawa et al (1991) understood that over streets that are around 100 meters wide and face a river, horizontal cooling moves up to $400 \mathrm{~m}$ in. Over the course of narrower streets (around $10 \mathrm{~m}$ wide) which had heavy traffic on them, the horizontal cooling could not move further from 50-150 $\mathrm{m}$.

In addition, the water body size and water distribution over the city has its role. Quietly huge water bodies also seem to acquire a relatively powerful cooling impact on the surroundings. Although a number of smaller lakes have shown to influence bigger percentages of cities.

This is in line on the findings from the research of Sun and Chen (2012), in the study which focused on the impact of the geometry of the water body. With implementation of large-eddy simulation that study concluded that a number of smaller normally shaped bodies of water have the highest beneficial impact when it comes to the matter of lowering extreme temperature over the course of the day (Theeuwes et al, 2013).

Water shading via trees provides lower temperatures and enriches the thermal environment (Hathway and Sharples, 2012; Li et al, 2011; Robitu et al. 2006). The water misting is also influential for cooling. Nishimura et al (1998) analysed the influences of a fountain inside a park in Osaka (Japan). They understood that there is a significantly bigger cooling impact when the fountain was running or was off, above all the in direction $\mathrm{f}$ leeward $\left(1.8\right.$ compared to $\left.4.7^{\circ} \mathrm{C}\right)$. 
Ishshii et al (1991) analysed the thermal environment from a pond in central park of Fukuoka city, Japan, and got the benefit from a government project in an act to clean the pond sludge via a thorough drainage. Afterwards, they conducted research in the interval when the pond got drained and in the interval, the pond was refilled with the acquired water. The temperatures for the water filled situation and the water drained situation were compared to the sites from urban reference, thus calculating the size of impact. The subtraction of the sizes of the effect for water drained and water filled situation resulted in the absolute, isolated thermal impacts of urban blue without the urban green. On the average, the temperature inside park which had water was $0.4{ }^{\circ} \mathrm{C}$ cooler than when it did not have water. In comparison to the temperatures of the residential surrounding areas nearby, the park which had water was $1.2^{\circ} \mathrm{C}$ cooler than with it had not.

Kim et al. (2008) in Seoul, South Korea, had done a similar research in which a channelled stream was going to be restored inside the central district. In this case, the UHI was normally pretty intensive. Over the case of the study temperatures got measured before, during and after the act of stream restoration over three years during August in comparison to one urban reference site. The distribution of calculated effect measurements in the central district prior and after restoration can lead to a quantitative impact size. After the act of restoration, the urban district was averagely around $0.6^{\circ} \mathrm{C}-1{ }^{\circ} \mathrm{C}$ cooler in comparison to the urban area around $200 \mathrm{~m}$ distant.

Not all the determinants were selected in all studies; researchers usually only concentrated on the ones relevant to their related to the specific research question. The complex interaction of temperature mitigation efficacy of urban water bodies still requires to be more thoroughly researched.

Strategies of urban geometry design in the urban areas can promote the cooling impacts from water bodies. By reviewing various other studies inside microclimate and urban design and the role that water bodies have inside cities, it is quite clear that a lot of studiers focus on the parks, squares or gardens and so hardly we can see a study that focused on the influence of the street geometry and urban geometry, considering high of the buildings and width of the streets to work on the cooling effects from the water bodies down to the patterns of the streets inside inner parts of the patterns that streets have. There are a number of researches that studied the impact of the effects of vegetation or other related variables in the geometry of streets, but there is still a gap between street geometries and water bodies.

Finally, this specific review does not consideration explicitly with regard to mixing water. Within the summer season, once the warm water with the least density compiles near the top of the water, the stratification prevents top to bottom mixing up water from lower cool layers. Additionally mixing up induced through wind flow more than water is quite confined due to decreased wind flow pace in the location. Entire, this specific device is in charge of a more substantial diurnal cycle in the water compared to with well-mixed water, and so the less chilling or even increased temperatures effect in the daytime.

Even though water absorbs a lot of heat, water is usually good heat sinks considering that the heat does not make a substantial increase water temperature as a result of water bodies' thermal inertia in addition to evaporation with the area. The actual inertia of water is directly proportional to water mass and so to the depth. Along with raising water body inertia, the water temperature lessens along with lowering water body inertia as a consequence of water turbulence mixing up; the issues due to turbulent water places might not exactly once we expect not to influence connected with shore breezes.

\section{Discussion}

A number of studies showed that the water bodies in urban areas do possess a cooling influence on their surroundings (e.g. Theeuwes et al, 2013, Xu et al., 2010 and Robitu et al, 2006).

This review decided to collect present evidence for temperature mitigation influences of urban bodies of water as some sort of possible support for the decrease of heat stress and UHI. All of the works which were analysed have reported a decrease of temperature near water bodies in comparison to urban regions near the sites of reference. Although, there will be still far smaller number of studies on water bodies than on the vegetation.

Talking about the physic of the water bodies they have a pretty large heat capacity in comparison to the surroundings. Obviously, this is shown in the temperature at the screen level, and also the UHI. This influence is also clear on the maximum UHI that happens in the evening (Steeneveld et al 2014). Our study proposes that a big body of water cannot be an a-priori act in a positive way on thermal comfort, since one of its elements, I.e., temperature is always kept at somehow high levels near the water bodies.

Additionally this study results show that the cooling influence of water is merely relevant over daytime, while at the course of night we see a type of less explained warming influence. Specifically at night time the thermal comfort is vital for getting sleep. 
Environmental situations from nearby areas like wind turbulence, wind velocity, temperature, humidity and wind direction influence the cooling range of bodies of water (Chen et al, 2009; Murakawa et al, 1991; Coutts et al 2012; Nishimura et al, 1998; Robitu et al, 2006). A farther understanding of the role that water has in urban areas may be explored. Particularly, various effective factors like the geometry expressed in the landscape shape index, water body area, surrounding built-up pro-portion and distance from the city centre (Sun \& Chen, 2012). Sadly, the physical reason behind the findings remains unknown and is yet open for further research.

\section{Conclusion}

Heat waves are a great heat concern in varying climate. This review concentrated on studies working on the climate mitigation influences of water bodies. In summer, different kinds of water bodies have the capacity to cool the ambient temperature for the air. Extreme weather events such as heat waves, with the eventual heat stress for urban dwellers are attenuated by bodies of water.

Upcoming studies must be undertaken in regard to the different neighboring and confounding environmental conditions in order to refine data in a sense to have more precise reference to water bodies and hence empower the evidence.

Another important problem that is addressed by some studies focuses on the influence of water bodies on the temperature in regard to the size and distance of water. The diffusion of various types of water bodies is a vital issue for health and urban planners and policy makers and must therefore be concentrated on in more upcoming studies.

The temperature mitigation capacity of water may reduce health risks that are caused by heat waves, even though the higher levels of humidity that is caused by water should also be considered in the shape of a potential risk to health in addition to the appearance of the vector borne infectious diseases. In order to make healthy environments in future cities, a more improved understanding of the water capacity is required in an attempt get opportunities for the action.

This shows that bodies of water do not do a priori act in shape of cooling elements in urban areas as it was believed before, specifically overnight time and evenings in the final quarters of summer, when the water on the surface is pretty warm.

Water that has a lower temperature in comparison to its surroundings will always work as a cooling factor and also vice versa. In this method, the water has a role of a buffer for the diurnal temperature cycle; it cools the environment over the course of day and makes it cool at night. A consequence of this study can be that when bodies of water have reached a higher rate of temperature over the hot seasons, they are capable of acting as night warming elements, and hence can be adverse to the thermal comfort.

\section{Acknowledgments}

I'd like to thank the faculty of Built Environment, University Technology Malaysia. This research was conducted as a part of the PhD thesis of the author in "THE INTERACTION OF WATER BODY AND STREET GEOMETRY ON MICROCLIMATE IN MITIGATING HEAT STRESS IN TROPICAL CITY OF MELAKA". The opinions expressed here are, however, the author's own. A number of the referees for this paper also made useful suggestions, many of which have been incorporated.

\section{References}

Andreou, E. (2013). Thermal comfort in outdoor spaces and urban canyon microclimate. Renewable Energy, 55, 182-188.

Andreou, E., \& Axarli, K. (2012). Investigation of urban canyon microclimate in traditional and contemporary environment. Experimental investigation and parametric analysis. Renewable Energy, 43, 354-363.

Arnfield, A. J. (2003). Two decades of urban climate research: a review of turbulence, exchanges of energy and water, and the urban heat island. International journal of climatology, 23(1), 1-26.

Bowler, D. E., Buyung-Ali, L., Knight, T. M., \& Pullin, A. S. (2010b). Urban greening to cool towns and cities: A systematic review of the empirical evidence. Landscape and Urban Planning, 97(3), 147-155.

Bowler, D., Buyung-Ali, L., Knight, T., \& Pullin, A. (2010a). How effective is 'greening'of urban areas in reducing human exposure to ground level ozone concentrations, UV exposure and the 'urban heat island effect'. Retrieved from www. environmentalevidence. org/SR41. html.

Chang, C. R., Li, M. H., \& Chang, S. D. (2007). A preliminary study on the local cool-island intensity of Taipei city parks. Landscape and Urban Planning, 80(4), 386-395. 
Chen, X. L., Zhao, H. M., Li, P. X., \& Yin, Z. Y. (2006). Remote sensing image-based analysis of the relationship between urban heat island and land use/cover changes. Remote Sensing of Environment, 104(2), 133-146.

Chen, Z., Zhao, L., Meng, Q., Wang, C., Zhai, Y., \& Wang, F. (2009). Field measurements on microclimate in residential community in Guangzhou, China. Frontiers of Architecture and Civil Engineering in China, 3(4), 462-468.

Claßen, T., Heiler, A., Brei, B., \& Hornberg, C. (2013). Gesundheitsrisiko Klimawandel: eine lösbare Aufgabe für Regionen und Kommunen?! Klimawandel und Gesundheit (pp. 259-278): Springer.

Coca, M. A. A. (1992). Aspectos climáticos del parque del Retiro (Madrid). Estudios geográficos, 53(207), 217-240.

Comrie, A. (2007). Climate change and human health. Geography Compass, 1(3), 325-339.

Coutts, A. M., Tapper, N. J., Beringer, J., Loughnan, M., \& Demuzere, M. (2013). Watering our cities The capacity for Water Sensitive Urban Design to support urban cooling and improve human thermal comfort in the Australian context. Progress in Physical Geography, 37(1), 2-28.

Dimoudi, A., \& Nikolopoulou, M. (2003). Vegetation in the urban environment: microclimatic analysis and benefits. Energy and buildings, 35(1), 69-76.

D'Ippoliti, D., Michelozzi, P., Marino, C., de'Donato, F., Menne, B., Katsouyanni, K., ... Paldy, A. (2010). Research The impact of heat waves on mortality in 9 European cities: results from the EuroHEAT project.

EEA (EUROPEAN ENVIRONMENT AGENCY) (2012): Climate change, impacts and vulnerability in Europe 2012 - an indicator-based report. European Environment Agency, Copenhagen. Retrieved from http://www.eea.europa. eu/publications/climate-impacts-and-vulnerability-2012/at_download/file (Date 20.11.2013)

Emmanuel, R., \& Johansson, E. (2006). Influence of urban morphology and sea breeze on hot humid microclimate: the case of Colombo, Sri Lanka. Climate research, 30(3), 189-200.

Füssel, H. M., Jol, A., Kurnik, B., Hemming, D., Hartley, A., Hildén, M., ... Kristensen, P. (2012). Climate change, impacts and vulnerability in Europe 2012: An indicator-based report. EEA Report, 12.

Givoni, B. (1991). Impact of planted areas on urban environmental quality: a review. Atmospheric Environment. Part B. Urban Atmosphere, 25(3), 289-299.

Givoni, B., Noguchi, M., Saaroni, H., Pochter, O., Yaacov, Y., Feller, N., \& Becker, S. (2003). Outdoor comfort research issues. Energy and buildings, 35(1), 77-86.

Hajat, S., O'Connor, M., \& Kosatsky, T. (2010). Health effects of hot weather: from awareness of risk factors to effective health protection. The Lancet, 375(9717), 856-863.

Han, G., Chen, H., Yuan, L., Cai, Y., \& Han, M. (2011). Field measurements on micro-climate and cooling effect of river wind on urban blocks in Wuhan city. Paper presented at the Multimedia Technology (ICMT), 2011 International Conference on.

Hathway, E. A., \& Sharples, S. (2012). The interaction of rivers and urban form in mitigating the Urban Heat Island effect: A UK case study. Building and Environment, 58(0), 14-22. http://dx.doi.org/10.1016/j.buildenv.2012.06.013

Heusinkveld, B. G., Van Hove, L., Jacobs, C., Steeneveld, G., Elbers, J., Moors, E., \& Holtslag, A. (2010). Use of a mobile platform for assessing urban heat stress in Rotterdam. Paper presented at the Proceedings of the 7th Conference on Biometeorology Albert-Ludwigs-University of Freiburg, Germany.

Hou, P., Chen, Y., Qiao, W., Cao, G., Jiang, W., \& Li, J. (2013). Near-surface air temperature retrieval from satellite images and influence by wetlands in urban region. Theoretical and applied climatology, 111(1-2), 109-118.

Huang, H. Y., Margulis, S. A., Chu, C. R., \& Tsai, H. C. (2011). Investigation of the impacts of vegetation distribution and evaporative cooling on synthetic urban daytime climate using a coupled LES-LSM model. Hydrological processes, 25(10), 1574-1586.

Huang, L., Li, J., Zhao, D., \& Zhu, J. (2008a). A fieldwork study on the diurnal changes of urban microclimate in four types of ground cover and urban heat island of Nanjing, China. Building and Environment, 43(1), 7-17.

Ihara, T., Kusaka, H., Hara, M., Matsuhashi, R., \& Yoshida, Y. (2011). Estimation of Mild Health Disorder Caused by Urban Air Temperture Increase with Midpoint-Type Impact Assessment Methodology. Journal of 
Environmental Engineering(Transaction of AIJ), 76(662), 459-467.

Inard, C., Groleau, D., \& Musy, M. (2004). Energy balance study of water ponds and its influence on building energy consumption. Building Services Engineering Research and Technology, 25(3), 171-182.

IPCC. (2007). Fourth assessment report. Cambridge, Retrieved from https://www.ipcc.ch/publications_and_data/ publications_and_data_reports.shtml

Ishii, A., Iwamoto, S., Katayama, T., Hayashi, T., Shiotsuki, Y., Kitayama, H., ... Nishida, M. (1991). A comparison of field surveys on the thermal environment in urban areas surroundings a large pond: when filled and when drained. Energy and buildings, 16(3), 965-971.

Jáuregui, E. (1991). Effects of revegetation and new artificial water bodies on the climate of northeast Mexico City. Energy and buildings, 15(3), 447-455.

Jusuf, S. K., Hien, W. N., \& Syafii, N. I. (). Influence of Water Feature on Temperature Condition in Hot Humid Climate.

Kim, Y. H., Ryoo, S. B., Baik, J. J., Park, I. S., Koo, H. J., \& Nam, J. C. (2008). Does the restoration of an inner-city stream in Seoul affect local thermal environment? Theoretical and applied climatology, 92(3-4), 239-248.

Kjellstrom, T., Butler, A. J., Lucas, R. M., \& Bonita, R. (2012). Public health impact of global heating due to climate change: potential effects on chronic non-communicable diseases. International journal of public health, 55(2), 97-103.

Kleerekoper, L., van Esch, M., \& Salcedo, T. B. (2012). How to make a city climate-proof, addressing the urban heat island effect. Resources, Conservation and Recycling, 64, 30-38.

Kovats, R. S., \& Hajat, S. (2008). Heat stress and public health: a critical review. Annu. Rev. Public Health, 29, 41-55.

Krüger, E., \& Pearlmutter, D. (2008). The effect of urban evaporation on building energy demand in an arid environment. Energy and buildings, 40(11), 2090-2098.

Li, J., Song, C., Cao, L., Zhu, F., Meng, X., \& Wu, J. (2011). Impacts of landscape structure on surface urban heat islands: a case study of Shanghai, China. Remote Sensing of Environment, 115(12), 3249-3263.

Lopes, A., Lopes, S., Matzarakis, A., \& Alcoforado, M. J. (2011). The influence of the summer sea breeze on thermal comfort in Funchal (Madeira). A contribution to tourism and urban planning. Meteorologische Zeitschrift, 20, 553-564.

Makhelouf, A. (2009). The effect of green spaces on urban climate and pollution. Iranian Journal of Environmental Health Science \& Engineering, 6(1).

MASIERO, É., \& DE SOUZA, L. C. L. (). Influence of a Waterbody in the Urban Microclimate.

Matthies, F., Bickler, G., Marín, N. C., \& Hales, S. (2008). Heat-health action plans: guidance: World Health Organization.

Murakawa, S., Sekine, T., Narita, K. i., \& Nishina, D. (1991). Study of the effects of a river on the thermal environment in an urban area. Energy and buildings, 16(3), 993-1001.

Nakayama, T., \& Fujita, T. (2010). Cooling effect of water-holding pavements made of new materials on water and heat budgets in urban areas. Landscape and Urban Planning, 96(2), 57-67.

Nishimura, N., Nomura, T., Iyota, H., \& Kimoto, S. (1998). Novel water facilities for creation of comfortable urban micrometeorology. Solar Energy, 64(4), 197-207.

Oke, T. R. (1992). Boundary layer climates: Psychology Press.

Olah, A. (2012). The Possibilities of Decreasing The Urban Heat Island. Applied Ecology And Environmental Research, 10(2), 173-183.

Oliveira, S., Andrade, H., \& Vaz, T. (2011). The cooling effect of green spaces as a contribution to the mitigation of urban heat: A case study in Lisbon. Building and Environment, 46(11), 2186-2194.

Pauli, A., \& Hornberg, C. (2010). Sozialräumliche und gesundheitsbezogene Implikationen des Klimawandels im Kontext von Klimaschutz und Klimaanpassung. In: Verhaltenstherapie \& Psychosoziale Praxis, 42, 313-329.

Peng, H., Weiguo, J., Guangzhen, C., \& Ai'Min, L. (2009). Effect of urban thermal characteristics on wetlands 
based on remote sensing and GIS. Paper presented at the Urban Remote Sensing Event, 2009 Joint.

Peng, S., Piao, S., Ciais, P., Friedlingstein, P., Ottle, C., Bréon, F. o.-M., ... Myneni, R. B. (2012). Surface urban heat island across 419 global big cities. Environmental science \& technology, 46(2), 696-703.

Qiu, G. Y., Li, H. Y., Zhang, Q. T., Chen, W., Liang, X. J., \& Li, X. Z. (2013). Effects of Evapotranspiration on Mitigation of Urban Temperature by Vegetation and Urban Agriculture. Journal of Integrative Agriculture, 12(8), 1307-1315.

Rinner, C., \& Hussain, M. (2011). Toronto's urban heat island—Exploring the relationship between land use and surface temperature. Remote Sensing, 3(6), 1251-1265.

Robitu, M., Musy, M., Inard, C., \& Groleau, D. (2006). Modeling the influence of vegetation and water pond on urban microclimate. Solar Energy, 80(4), 435-447.

Rydin, Y., Bleahu, A., Davies, M., Dávila, J. D., Friel, S., De Grandis, G., \& Howden-Chapman, P. (2012). Shaping cities for health: complexity and the planning of urban environments in the 21 st century. Lancet, 379(9831), 2079.

Saaroni, H., \& Ziv, B. (2003). The impact of a small lake on heat stress in a Mediterranean urban park: the case of Tel Aviv, Israel. International Journal of Biometeorology, 47(3), 156-165.

Santamouris, M., \& Asimakopoulos, D. (2001). Energy and climate in the urban built environment.

Santamouris, M., Papanikolaou, N., Livada, I., Koronakis, I., Georgakis, C., Argiriou, A., \& Assimakopoulos, D. (2001). On the impact of urban climate on the energy consumption of buildings. Solar Energy, 70(3), 201-216.

Schwarz, N., Schlink, U., Franck, U., \& Großmann, K. (2012). Relationship of land surface and air temperatures and its implications for quantifying urban heat island indicators - an application for the city of Leipzig (Germany). Ecological Indicators, 18, 693-704.

Shashua-Bar, L., Tsiros, I. X., \& Hoffman, M. (2012). Passive cooling design options to ameliorate thermal comfort in urban streets of a Mediterranean climate (Athens) under hot summer conditions. Building and Environment, 57, 110-119.

Shudo, H., Sugiyama, J., Yokoo, N., \& Oka, T. (1997). A study on temperature distribution influenced by various land uses. Energy and buildings, 26, 199-205.

Smith, C., \& Levermore, G. (2008). Designing urban spaces and buildings to improve sustainability and quality of life in a warmer world. Energy Policy, 36(12), 4558-4562.

Spronken,Smith, R. A., Oke, T. R., \& Lowry, W. P. (2000). Advection and the surface energy balance across an irrigated urban park. International Journal of Climatology, 20(9), 1033-1047.

Steeneveld, G., Koopmans, S., Heusinkveld, B., \& Theeuwes, N. (2014). Refreshing the role of open water surfaces on mitigating the maximum urban heat island effect. Landscape and Urban Planning, 121, 92-96.

Steeneveld, G., Koopmans, S., Heusinkveld, B., Van Hove, L., \& Holtslag, A. (2011). Quantifying urban heat island effects and human comfort for cities of variable size and urban morphology in the Netherlands. Journal of Geophysical Research: Atmospheres (1984-2012), 116(D20).

Sun, R., \& Chen, L. (2012). How can urban water bodies be designed for climate adaptation? Landscape and Urban Planning, 105(1-2), 27-33. http://dx.doi.org/10.1016/j.landurbplan.2011.11.018

Sun, R., Chen, A., Chen, L., \& Lü, Y. (2012). Cooling effects of wetlands in an urban region: The case of Beijing. Ecological Indicators, 20, 57-64.

Taha, H. (1997). Urban climates and heat islands: albedo, evapotranspiration, and anthropogenic heat. Energy and buildings, 25(2), 99-103.

Taha, H., Akbari, H., Rosenfeld, A., \& Huang, J. (1988). Residential cooling loads and the urban heat island - the effects of albedo. Building and Environment, 23(4), 271-283.

Theeuwes, N., Solcerová, A., \& Steeneveld, G. (2013). Modeling the influence of open water surfaces on the summertime temperature and thermal comfort in the city. Journal of Geophysical Research: Atmospheres, 118(16), 8881-8896.

Upmanis, H., Eliasson, I., \& Lindqvist, S. (1998). The influence of green areas on nocturnal temperatures in a high latitude city (Göteborg, Sweden). International journal of climatology, 18(6), 681-700. 
Voelker, S., Baumeister, H., Claßen, T., Hornberg, C., \& Kistemann, T. (2013). Evidence For The Temperature-Mitigating Capacity Of Urban Blue Space-A Health Geographic Perspective. Erdkunde, 67(4).

Völker, S., \& Kistemann, T. (2011). The impact of blue space on human health and well-being-Salutogenetic health effects of inland surface waters: A review. International journal of hygiene and environmental health, 214(6), 449-460.

Völker, S., \& Kistemann, T. (2013). “I'm always entirely happy when I'm here!” Urban blue enhancing human health and well-being in Cologne and Düsseldorf, Germany. Social Science \& Medicine, 78, 113-124.

Weng, Q., \& Yang, S. (2004). Managing the adverse thermal effects of urban development in a densely populated Chinese city. Journal of Environmental Management, 70(2), 145-156.

WHO and WMO (WORLD METEOROLOGICAL ORGANIZATION) (2012): Atlas of health and climate. Geneva. Retrieved November 20, 2013, from http://www.who.int/iris/bitstre am/10665/76224/5/9789241564526_eng.pdf

WMO (WORLD METEOROLOGICAL ORGANIZATION). (2010). Guide to climatological practices WMO-No. $100 \quad$ (third edition). Retrieved from http://www.wmo.int/ pages/prog/wcp/documents/Guidefulltext.pdf (Date: 20.11.2013)

Wong, N. H., Tan, C. L., Nindyani, A. D. S., Jusuf, S. K., \& Tan, E. (2012). Influence of water bodies on outdoor air temperature in hot and humid climate. Paper presented at the Reston, VA: ASCE copyright Proceedings of the 2011 International Conference on Sustainable Design and Construction| d 20120000.

Xu, J., Wei, Q., Huang, X., Zhu, X., \& Li, G. (2010). Evaluation of human thermal comfort near urban waterbody during summer. Building and Environment, 45(4), 1072-1080.

Yahia, M. W., \& Johansson, E. (2013). Influence of urban planning regulations on the microclimate in a hot dry climate: The example of Damascus, Syria. Journal of Housing and the Built Environment, 1-15.

\section{Copyrights}

Copyright for this article is retained by the author(s), with first publication rights granted to the journal.

This is an open-access article distributed under the terms and conditions of the Creative Commons Attribution license (http://creativecommons.org/licenses/by/3.0/). 